\title{
Gates in Late Antiquity in the Eastern Mediterranean
}

\author{
Ine Jacobs
}

\begin{abstract}
In Late Antiquity, cities and other important settlements in the Eastern Mediterranean almost completely disappeared from view behind massive fortifications. The walled areas could then only be entered through a small number of highly visible gates. This article investigates the physical appearance of these gates. It presents an overview of their basic requirements and their additional architectural and figurative decoration. It then attempts to explain why these features were used and how this relates to the nature of the settlement - imperial capital, 'normal' city, border town or Christian sanctuary - to which they belonged.*
\end{abstract}

\section{INTRODUCTION}

The most conspicuous monumental achievements of Late Antiquity visible today are without doubt urban fortifications and Christian churches. The high visibility of both building types results from the solidness of their construction, which, at least in the case of fortifications, was required to fulfil their initial purpose of defence. However, unlike churches in which luxury was most often a compulsory constituent, the circuit wall has generally been considered a more prosaic component of the late antique city, an obligatory adjustment of the open Roman town to the 'troubled circumstances of the period'. When structures were erected for a functional purpose, this does not automatically imply that they cannot comprise imaginative elements intended for other, less-pressing objectives.

The most visible sections of an urban fortification were those through which all traffic to and from the centre had to pass - the gates. Indeed, it is hardly surprising that they came to play an extraordinary part in shaping and presenting a town to outsiders. ${ }^{1}$ Just as the frontage and main entrance of a public building or house was the first feature with which a visitor came into contact, so were the fortification walls and the passages into the enclosed area conceived as the façades of a settlement, whether the circuit wall surrounded the entire built-up area or not.

This article will attempt to assess which considerations influenced the appearance of late antique gates and to what degree. First of all, we need to establish what the basic shape of a late antique city gate was, and how and why it differed from earlier Greek and Roman gates. Subsequently, an overview of features added to this basic form will be presented, followed by a discussion of their spread and purpose. For this task, the Theodosian gates of Constantinople will be compared with the (more or less) contemporary gates of provincial capitals and smaller towns of Asia Minor, to which fortifications were a later addition, and with the gates of some of the better known newly created settlements, which include both eastern border towns laid out under imperial auspices and Christian pilgrimage centres. ${ }^{2}$ The diverse nature and status of these settlements, and perhaps also the nature of the threats they faced, are likely to have influenced the appearance of their fortifications and gates. As we are looking for representative elements, chiefly the larger gates of a town - those erected over its main axes - are important since they were used for non-local traffic.

\section{A SHORT HISTORY OF THE CITY GATE}

The shape of a city gate normally reflects more general conditions of the Roman Empire, or at least those of the region. The first Greek gates were no more than openings in the city wall, created to give access to the enclosed area but equally to defend it. ${ }^{3}$ In the Hellenistic period, these openings were joined by two towers, jutting outwards on both sides of the passage. Since a small courtyard was thus created in front of the passage, this is referred to as the forecourt type of gateway. ${ }^{4}$ Incorporating decorative elements into these gates was rarely practised but there were notable exceptions - for instance, the triglyph-frieze incorporated into the Hellenistic Gate of Perge and the weaponry friezes on many of the city gates in Pamphylia and Pisidia constructed in the $3^{\text {rd }}$ and $2^{\text {nd }}$ centuries BC. ${ }^{5}$

Although, in the Early Imperial period, few gates 


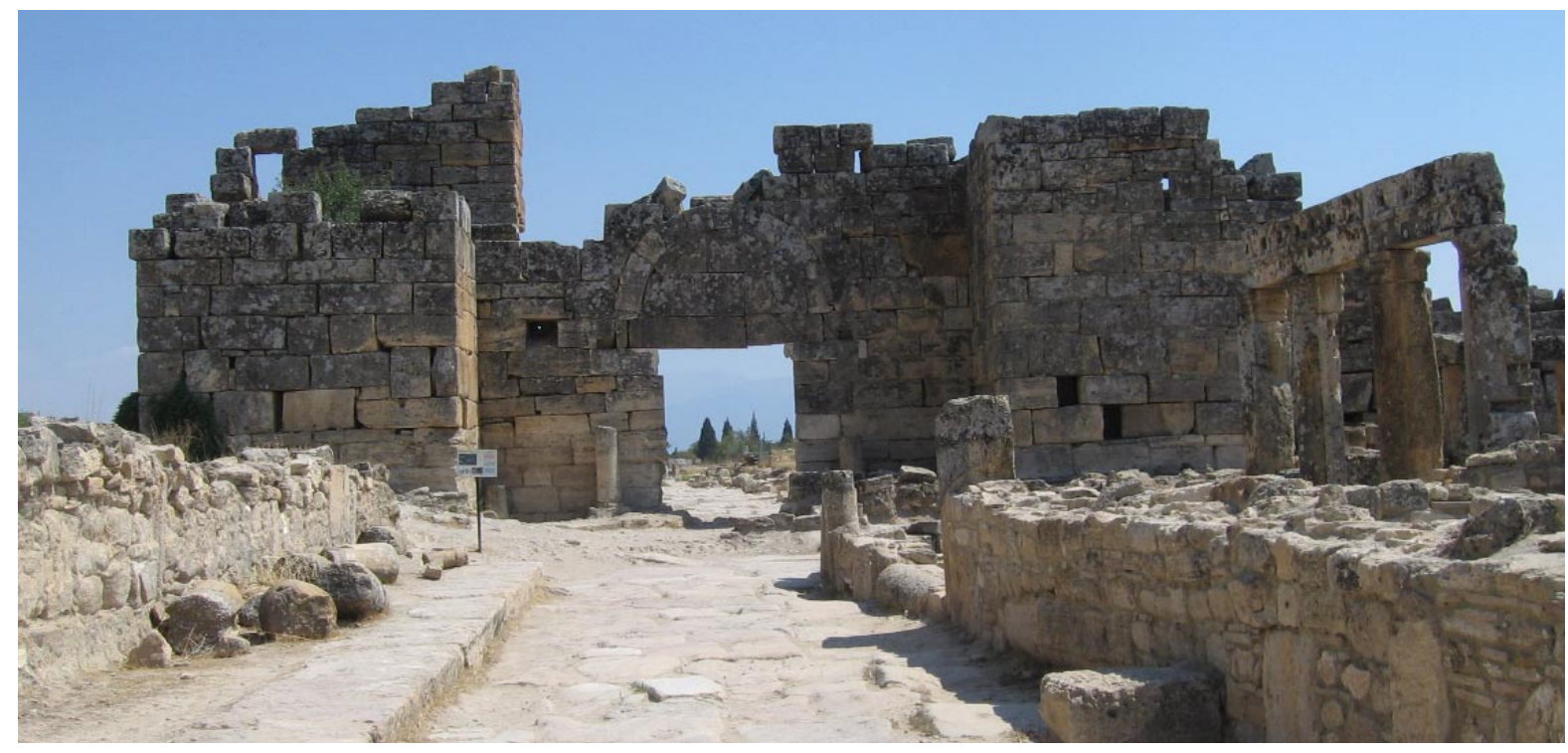

Fig. 1. North Gate at Hierapolis (photo author).

were erected in the region of Asia Minor, both the western half of the Empire and the Near East saw the appearance of the so-called Prunktore. ${ }^{6}$ By this time, the defences of the Roman Empire had been relocated to its borders. Since they were therefore no longer indispensable to the security of a city, fortification walls became symbolic delimitations of its built-up area. Their gates could still be closed if necessary, but they were intended first and foremost to express the status and wealth of the city. ${ }^{7}$ As a consequence, they were given an elaborate architectural decoration. Traditionally, they intersected the city walls at right angles, ${ }^{8}$ possessed wide and high openings, and reflected the importance of the road they spanned. ${ }^{9}$ Although they had lost their defensive purpose, the gates acquired supplementary religious, juridical, administrative, and economical functions. Their religious function, connected to their nature as a passage and their role as a border between - real or conceived - inhabited and uninhabited areas, could be expressed in the gate itself by employing depictions of protective gods or, alternatively, by positioning sanctuaries nearby. Due to their favourable topographical location astride main streets where traffic was concentrated, commercial enterprises were set up in the area..$^{10}$ Moreover, they were ideal locations for collecting taxes on import or entrance into the city. ${ }^{11}$ This multi-functionality made the city gate important enough to become the emblema of the entire city from the $2^{\text {nd }}$ century $\mathrm{AD}$ onwards. ${ }^{12}$

In Late Antiquity, gates remained key locations for all sorts of activities. For instance, whenever a governor entered the city, he expected the leading citizens to meet him outside the gates. ${ }^{13}$ The presence of elevated sills at more than one gate indicates that traffic was intentionally slowed down, possibly in order to control those entering or leaving the city and/or in order to tax the passers-by. ${ }^{14}$ However, when city gates resumed a defensive purpose in Late Antiquity, this had repercussions for their appearance.

\section{Late ANTIQUe gates}

\section{Basic scheme}

With the return of the military function, the simple construction scheme of the forecourt type of gateway with its single narrow passage flanked by two towers became common once more. ${ }^{15}$ In cities such as Sagalassos, Perge, Side, and Selge, disused Hellenistic gates could again be restored; in cities such as Blaundos, Hierapolis, and Aphrodisias but also in Constantinople, Resafa and Zenobia, the Hellenistic design was copied.

All major gates in the Theodosian Land Walls of Constantinople were flanked by two rectangular towers. ${ }^{16}$ Likewise, the North Gate at Blaundos consisted of a narrow passage protected by two relatively square towers, as did the contemporary North and South Gates of Hierapolis (fig. 1), the West Gate of Aphrodisias, and the North-East and North-West Gate of Sagalassos. ${ }^{17}$ In this last-mentioned town, the newly constructed North-West Gate was a variation on the theme, as its two towers were actually a converted temple and heroon. The South Gate at Perge represented another vari- 

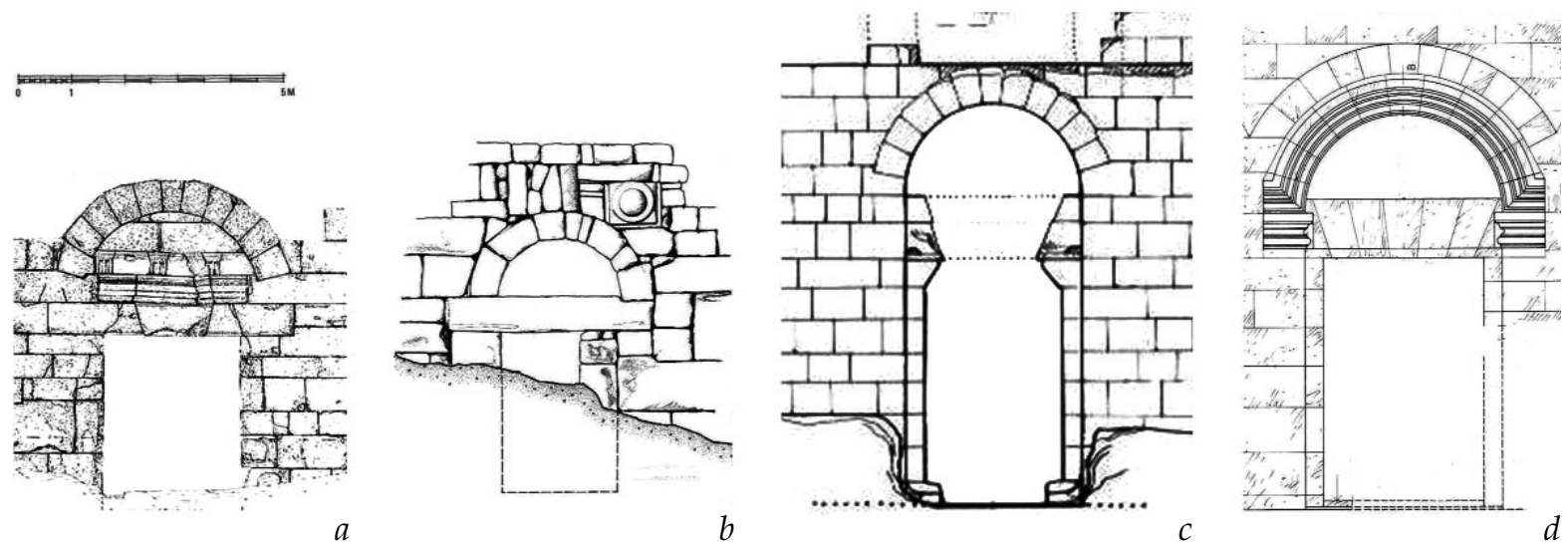

Fig. 2. Basic scheme of a late antique gate: comparison between (a) the North Gate of Blaundos, (b) a smaller gate at Selge, (c) the North Gate of Zenobia and (d) the East Gate of Resafa (drawing author).

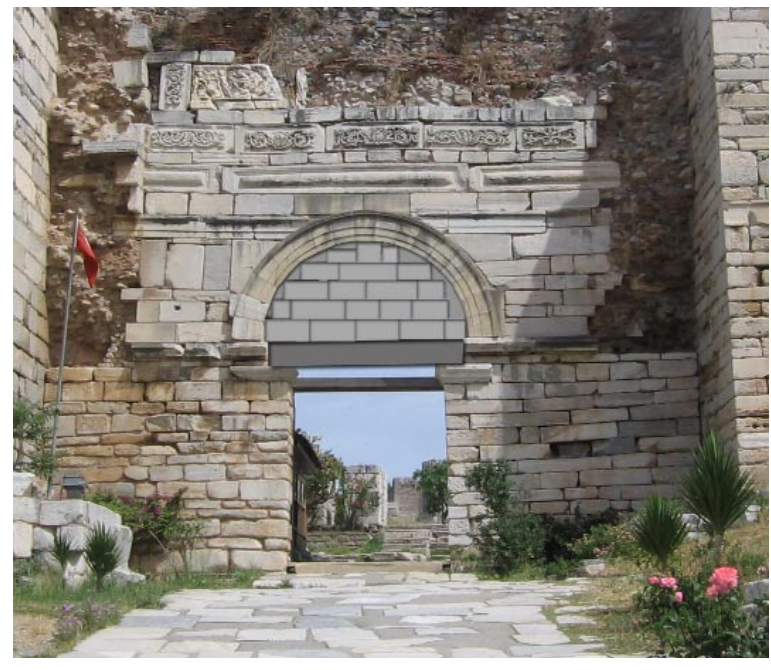

Fig. 3. Gate of Persecution at Ephesus with tentative reconstruction of its superstructure (photo author).

ation, as the towers were located at the end of two wall stretches, so that a larger courtyard was created. A more standard design was again found at the $6^{\text {th }}$ century gates of Resafa and Zenobia and the mid-6 th century (?) Gate of Persecution at Ephesus. ${ }^{18}$

The passages themselves were virtually all constructed according to the same principle: they were axial and consisted of only one narrow gate opening, with or without door posts, where one chariot at the same time could pass (fig. 2). The most typical feature of a late antique gate was its tympanum: this consisted of a lintel, or sometimes a double lintel, with an additional relieving arch on top but the field between lintel and arch was filled in. ${ }^{19}$ The infill above the lintel has often disappeared in later alterations, but we can safely assume that it was once there, since a gap would have weakened the defensive features of the gate. For instance, a secondary gate at Constantinople was altered in this manner and the presence of infill and lintel was attested only by the existence of holes in the arch. ${ }^{20}$ The Gate of Persecution at Ephesus may also have been built in its original form to the same scheme. The abaci, reused as impost blocks, nowadays no longer have a function, since the arch begins somewhat higher up and is wider. Their presence can only be explained if they once carried a horizontal lintel and possibly an infill between lintel and arch. If restored, the gate would resemble other late antique city arches to a greater degree (fig. 3).21

The arrangement with lintel and relieving arch clearly distinguishes late antique gate passages from Greek and Hellenistic gates that were often corbelled with one or two courses, or built with voussoired arches. Other solutions comprised the covering of the gate with a rectangular or triangular lintel. ${ }^{22}$ Roman gates were mostly arched and lacked a lintel. ${ }^{23}$

\section{Variations}

There were, of course, variations and exceptions to this rule, most of which were due to the incorporation of pre-existing monuments, some of which resulted from free choice.

When fortifications no longer were a necessity in the Roman period, the borders of a city or town would often be marked by monumental freestanding arches. ${ }^{24}$ Many of them were integrated into the new city walls in Late Antiquity, where they continued to be used as passageways. ${ }^{25}$ Since they then fulfilled a military-defensive purpose as well, 
the structure of these arches needed to undergo a number of changes. Firstly, they were provided with projecting towers. Secondly, their openings had to be narrowed, since they were too wide to be efficiently defended. Thirdly, gates and closing mechanisms needed to be installed and, finally, the exterior façade may have undergone certain modifications to ensure that the enemy could not find support when attempting to storm or breach the gate. ${ }^{26}$ The adaptation of an arch into a city gate differed from location to location. ${ }^{27}$ For instance, when the Golden Gate at Constantinople was modified into a city gate, its original passages were narrowed down with marble door frames, consisting of door posts crowned with Corinthian capitals. However, it appears that the blocking of side passages was a more common practice and no doubt it was also the safest. At the top of the east slope of the plateau on which the town of Kyaneai was situated, a triple arch served as a vista for those approaching the city. When it was converted at a later (undated) period, only its central passage served as the entrance to the town, whereas the other two archways were blocked off. ${ }^{28}$ Similar blocking-off is also known in other regions of the Eastern Roman Empire, where the integration of freestanding arches into fortifications was more widespread. ${ }^{29}$ For instance, the late $3^{\text {rd }}$ century (?) walls of Apamea protruded northwards to incorporate a free-standing arch erected $80 \mathrm{~m}$ in front of the original city walls, outside the town itself. Possibly in this first phase but definitely in its second Justinianic phase, only the central passage was still in use.

Some late antique gates possessed more than one opening. Although this would have assisted the smooth passage of traffic, ${ }^{30}$ the more passages a gate possessed, the more troublesome it became to defend. The Golden Gate at Constantinople had three passageways, which can be considered the product of its original function as a triumphal gate. ${ }^{31}$ The later $6^{\text {th }}$ century North Gate at Abu Mina also had three passages, a large one in the middle and two smaller ones to the sides. ${ }^{32}$ The nature of this settlement as a popular international Christian sanctuary may have made three passages a necessity. The South Gate at Blaundos apparently had two passages, both only ca $1.90 \mathrm{~m}$ wide and not suited for wheeled traffic, which due to terrain circumstances had to pass through the north gate. ${ }^{33}$

At Side, the Hellenistic defence wall was again taken into use in Late Antiquity. Its East Gate and Main Gate possessed two and three passages respectively, leading into a closed courtyard. In peaceful times, the town centre could be reached through passages in the courtyard's side walls and back wall (fig. 4). By the late $4^{\text {th }}$ century, the aforementioned side passages were walled up and only the narrow passage at the back was retained. The defence was thus concentrated at the back of the courtyard, so that the original number of passages in the front wall could be maintained. Nevertheless, the two passages at the East Gate were narrowed down as an extra precaution. ${ }^{34}$ With the exception of the West Gate, the gates of Resafa likewise possessed a courtyard (cavaedium gate) with three passages, but at the back of the courtyard rather than in the front wall. ${ }^{35}$

\section{ADDITIONAL ARCHITECTURAL EMBELLISHMENT}

The presence of more than one passage can already be considered a non-functional aspect of a city gate. In addition, many of them were given additional architectural and figurative embellishment.

\section{Gates with newly carved architectural decoration}

Since most late antique constructions in the towns of Asia Minor were composed of reused elements, the lack of new decoration on their gates is hardly surprising. Conversely, newly carved architectural decoration was encountered in the imperial capital, the border towns in the Near East, and the new Christian complexes. The original triumphal gate of Theodosius at Constantinople was only modestly decorated. Its lower mouldings and the cornice at the top were actually left unfinished. The inserted door frames were somewhat more sophisticated but were never finished at the back (fig. 5). ${ }^{36}$ The North Gate of Zenobia possessed the absolute minimum of architectural decoration, limited to a moulded profile on the two consoles. The town's second major gate, the South Gate, was apparently left undecorated. ${ }^{37}$ Only Gate V in the eastern wall section acquired a more complex moulded profile around the door and the arch above its lintel. The position of this gate at the end of one of the minor streets belonging to the Justinianic street system does not seem to be exceptional and, thus far, no explanation has come to light for its privileged treatment. 38

The mouldings around Gate V at Zenobia resembled those found at nearly every main gate at Resafa. ${ }^{39}$ As these gates comprised a courtyard, their defensive function could be concentrated on the unadorned front wall. Once the relative safety of the interior courtyard had been reached, representative functions gained precedence over military concerns. This was expressed in the luxurious 


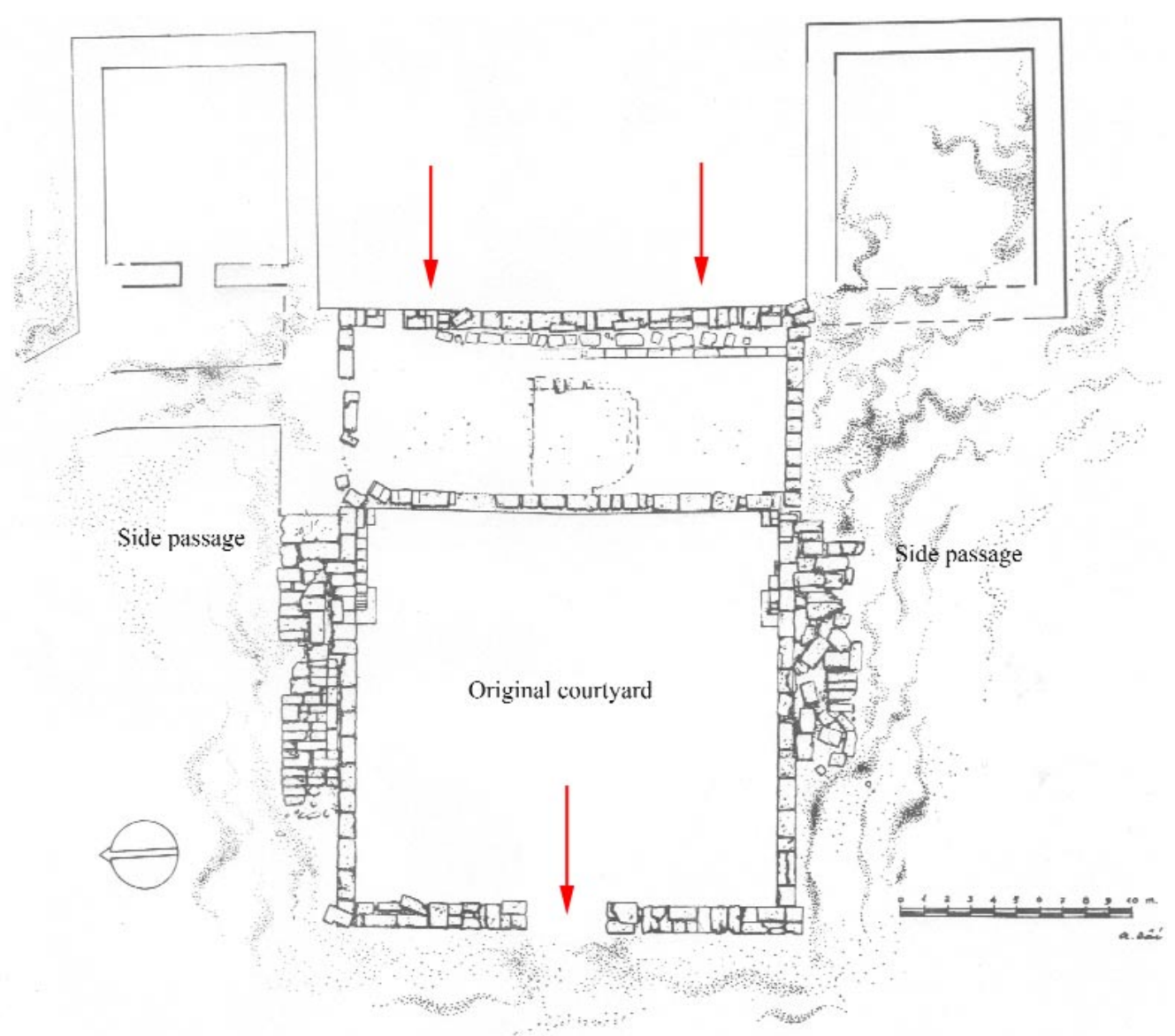

Fig. 4. East Gate at Side with double passage (based on Mansel 1968, 243, fig. 4).

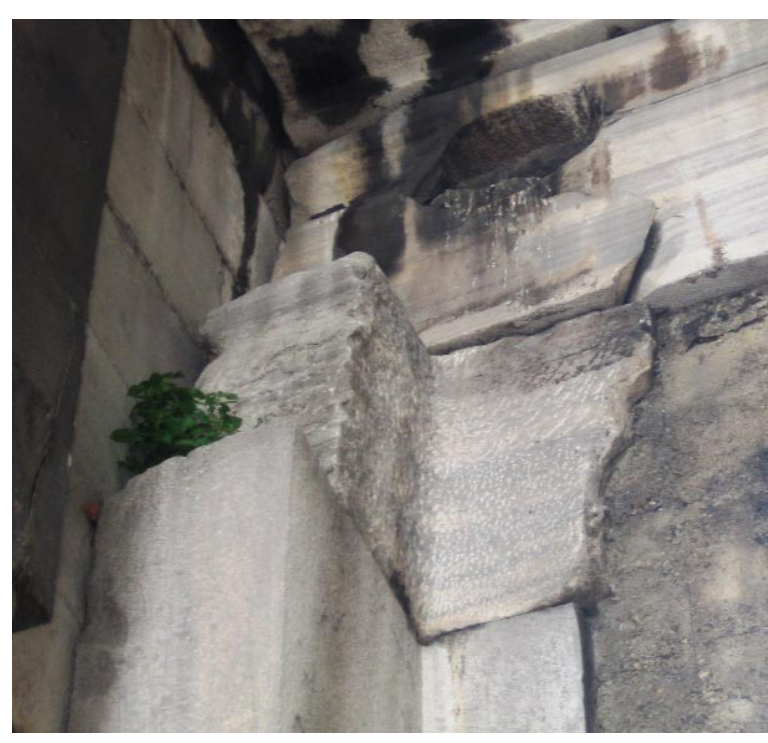

Fig. 5. Golden Gate at Constantinople, unfinished pilaster capital (photo author). architectural decoration on the back wall and, to a lesser degree, on the side walls. Around every passage, moulded profiles were present. There were additional ornamental niches, consoles and arched bands with moulded profiles. The North Gate, which can be considered the main entrance to the settlement, even possessed pilasters against its side walls and a columnar architecture on high pedestals framing the passage into the town. The significance of an extra defensive front wall in explaining the additional elaboration on the gates is confirmed by the decoration on the West Gate: in contrast to the other main gates, it was of the open forecourt type, consisting of a wall section intersected by one passage and flanked by two protruding towers. In contrast to the plain towers at the other gates, these were embellished with decorative pilasters connected by a horizontal moulded profile on their outside faces. The wall section inbetween both towers was adorned with a simple but elegant arched moulded band. The more complicated decoration on the exterior face of the gate 
may be explained by the fact that there was no possibility of decorating an interior wall, so decoration was moved outwards.

The elaborate decoration on the gates of Resafa sharply contrasts with the simple and functional gates of Zenobia. This aspect was in all likelihood indicative of the function of both towns: the first being a major Christian pilgrimage centre; the second a border town with mainly a military function. Other gates known to have possessed new architectural embellishment were also connected to Christian sanctuaries. The oldest of these examples can be found at the late $4^{\text {th }}$, early $5^{\text {th }}$ century AD Christian complex at Tebessa, where the South Gate in particular was richly adorned with mouldings. The walls on both sides of the passageway were preceded by two sets of two pedestals, which must once have carried freestanding columns, and behind these wall pilasters were present. The rear side of the arch was somewhat more modest, with only two columns on a simple base, which stood directly on the pavement. Nevertheless, their $9 \mathrm{~m}$ length also provided the north face with a monumental appearance. The only reused elements in this composition were the Corinthian capitals on top of the columns. The more elaborate decoration on this gate can again be explained by the fact that it was preceded by an original, purely functional barrier around the western side of the Sanctuary. ${ }^{40}$ The front face of the late $6^{\text {th }}$ century North Gate at Abu Mina was also decorated with half columns flanking the central passage and pilasters surrounding the side openings, despite having no closed forecourt in front of it. ${ }^{41}$

\section{Gates with Reused Decoration}

In the smaller towns of Asia Minor, building elements and architectural decoration could be purposefully reused to adorn the façade of their city gates. One of the most elaborate examples was the South Gate at Perge. This was preceded by a columnar architecture, the remains of which were found in the excavations and are still partly visible today. Its columns rested on two large square and two longer rectangular bases. Two sets of two columns were posted on the bases flanking the door, and only one on the bases in the corners. Together with the $1.5 \mathrm{~m}$ high bases, they reached a height of ca $5.40 \mathrm{~m}$. The connection of their entablature to the wall is still visible. At Perge, these may have pre-dated the revalidation of the fortification ${ }^{42}$ but at Hierapolis a decorative columnar architecture was connected to the late antique North Gate itself: four columns were relocated to its front face and positioned symmetrically on both sides of the passage (fig. 1). Today, only their lower parts are preserved, but it can be assumed that they too were part of a more complete columnar architecture. Indeed, some $3 \mathrm{~m}$ high up in the wall, connection holes are still visible.

The gate in the south-eastern stretch of wall at Aphrodisias consisted of a reused architrave and archivolt, whereas the tympanon of the city's NorthEast Gate was on the inside surrounded by a lintel with egg-and-dart moulding above two stepped fasciae, of which one block has remained in situ (fig. 6). ${ }^{43}$ Likewise, above the lintel of the North Gate at Blaundos, an architrave with two fasciae has been inserted and, above this, a Doric frieze with three triglyphs and three metopes (fig. $2 a$ ). ${ }^{44}$ In addition, building elements found in the collapse material underneath the gate led to the assumption that the towers possessed a decoration composed of elements of a Doric architrave and a Doric triglyp-metope frieze. The only other fortification gate with a similar decoration was the Hellenistic Gate at Pergamon, whereas Doric friezes were also featured on honorific arches, for instance on the arch in the northern necropolis of Patara, constructed around AD $100 .{ }^{45}$ Finally, when the northern part of the city centre of Ephesus was walled at the end of Antiquity, 46 the gate installed in the northern wall of the Tetragonos Agora reused architectural fragments in a decorative manner. It was equipped with door posts carrying two larger rectangular blocks and heavily moulded impostlike blocks. Though these were no doubt used to provide greater stability, ${ }^{47}$ their incorporation was executed in such a manner that they contributed to the final aesthetic appearance of the gate.

\section{FIGURATIVE DECORATION}

Figurative adornment of city gates could consist both of freestanding statuary and relief decoration, whereas the presence of crosses on gates became more and more striking throughout Late Antiquity.

\section{Statuary and relief decoration}

The posting of honorific statuary on city gates was not unusual during Late Republican or Early Imperial times in the western half of the Empire.48 Similarly, the Hellenistic Main Gates of Perge and Side were converted into statuary showcases in the Roman period, where the former in particular was intended as a representation of its initiator, Plancia Magna. ${ }^{49}$ Both of them were safeguarded throughout Late Antiquity, with many of the orig- 


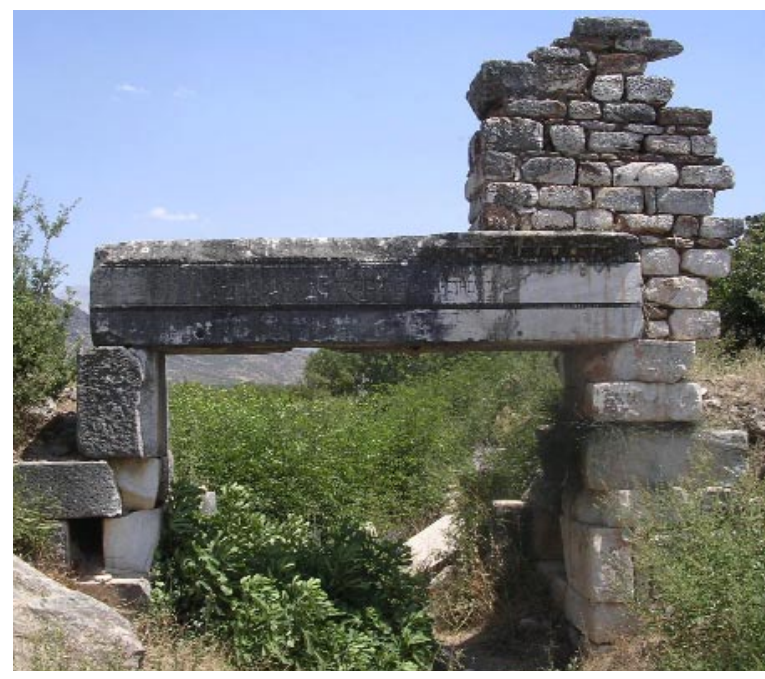

Fig. 6. North-East Gate at Aphrodisias, interior face (courtesy L. Lavan).

inal statues still partly, or even entirely, in existence at the time of excavation. However, new gates with freestanding statuary were extremely scarce. On the Golden Gate at Constantinople, which was intended to function as a triumphal arch, the presence of statues at the top of the gate was attested in literary sources and confirmed by the elevated number of dowel holes found on the top face of its cornices. ${ }^{50}$ The ensemble was very suited to a triumphal arch. It included two bronze elephants, presumably belonging to a biga or quadriga composition placed above the central passageway, and a statue of Theodosius, accompanied by a Nike and the Tyche of Constantinople. ${ }^{51}$ The only other late antique gates known to have been adorned with freestanding statues were likewise imperial capitals. The presence of statues at the main gates of Rome, which were restored under the reign of Honorius only a few years after the construction of the Golden Gate, was commemorated in inscriptions. ${ }^{52} \mathrm{~A}$ century earlier, the enceinte of Diocletian's residence at Split and especially its North Gate had been designed with an elaborate statuary programme in mind. ${ }^{53}$

When figurative decoration occurred in the towns of Asia Minor, its nature was different and it was almost invariably placed in a secondary position. Judging by the remains found near the Magnesian Gate at Ephesus for instance, marble statues of lions were probably posted in front of the passageway or flanked its portals, whereas finds of weaponry reliefs suggest these were still integrated into the most recent rebuilding of the gate. ${ }^{54} \mathrm{~A}$ fragment of a Hellenistic pediment with

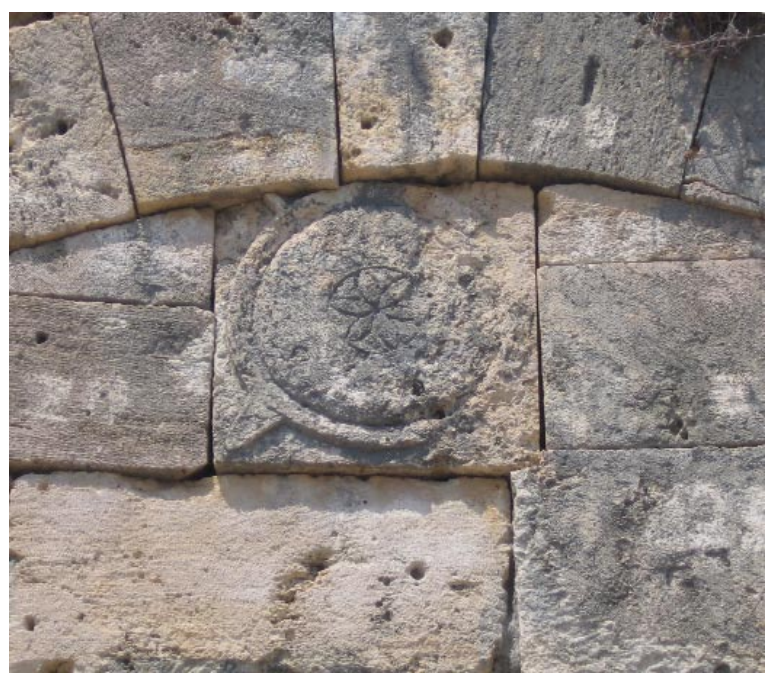

Fig. 7. Shield decoration on the South Gate of Perge (photo author).

a shield-like decoration in its centre was located in the passage of the Southwest Gate of Sardis. ${ }^{55}$ Because it was located in the lower section of the side wall of the gate, it can in this case be doubted, if the effect was intended. This was not so with similar shield decoration encountered in the cities of Side, Selge, Perge and Sagalassos. The incorporation of weaponry reliefs in the regions of Pisidia, Pamphylia and Lycia was a regional custom originating in the Hellenistic period ${ }^{56}$ and revived in Late Antiquity, either through the reuse of older reliefs or through new creations. At the East Gate of Side, a long ornamental frieze depicting a collection of armour pieces, helmets and swords was retrieved on top of a so-called 'Byzantine' mosaic, which makes it certain they were incorporated into the late version of the gate. ${ }^{57}$ At nearby Selge, comparable friezes were also found in the collapse layers under or next to several of its gates. Some of them may still have survived from the Hellenistic period; others were clearly re-erected at a later date..$^{58} \mathrm{~A}$ shield-motif was also applied above the South Gate at Perge but, in contrast to the other cities, it was newly carved (fig. 7).

Finally, at Sagalassos, weaponry friezes were incorporated into the late fortification wall. Those at the North-West Gate were unquestionably relocated from the town's Bouleuterion, along with busts of the warrior gods, Ares and Athena. ${ }^{59}$ While the weaponry friezes must have adorned the outer face of the walls on either side of the gate, the location where the two busts were found indicated that they were reused in the gate itself. Furthermore, the central keystone of the gate's arch de- 
corporated into the inscription, presumably in the late 6th century (fig. 6). ${ }^{66}$ As indicated above, the occurrence of crosses could be combined with other figurative reliefs, as occurred at Hierapolis and at Resafa. On other gates, crosses were added later, carved mostly on the door posts but also on adjoining wall sections. Examples include the Magnesian Gate at Ephesus, the west passage of the North Gate at Stratonikeia (fig. 9), and the wall abutting this gate in the west, as well as a South-East Gate of Aphrodisias. ${ }^{67}$

\section{MARBLE-MOSAICS-PAINTING}

The dressing of gate façades with marble or limestone and the application of mosaics on floors, walls and ceilings have been attested in only a few towns. For instance, the South Gate at Perge was surrounded by white limestone slabs that were left toothed at the sides; 68 the Golden Gate and its towers at Constantinople were completely constructed from marble, contrasting with the rest of the wall.

There are three instances in which a mosaic might have been applied to the gate and/or the area immediately surrounding it. A first instance can be found in the South-West Gate at Sardis, where large white tesserae underneath the vault of the side passage indicated the presence of a stretch of white, coarse mosaic, extending for $2 \mathrm{~m}$ underneath the vault and in front of it. ${ }^{69}$ Another mosaic, of a higher quality and applied to the gate itself, was present on the terrace above the East Gate at Side. ${ }^{70}$ This was a black-and-white mosaic with a band consisting of a garland and a wide bead-andreel motif, whereas the centre field was decorated with a geometric motif consisting of superposed, cutting circles. The presence of a mosaic floor in this location is particularly strange, as it would never be viewed by anyone other than the defenders of the gate. The only example where the mosaic was applied in the passageway itself, and thus visible to passers-by, was encountered at the West Gate of Resafa, which possessed a vault-mosaic, comprising white, black, grey, green and gold tesserae, of which remains have been found inbetween the collapse material. ${ }^{71}$ As mentioned earlier, the decoration scheme on the West Gate differed from the other main gates; since it did not have a closed courtyard, there was no separation between defensive and representational functions. In addition to supplementary pilasters on the towers, the application of a mosaic inside the vault of the gate was an alternative to the more elaborate architectural decoration on the other gates.

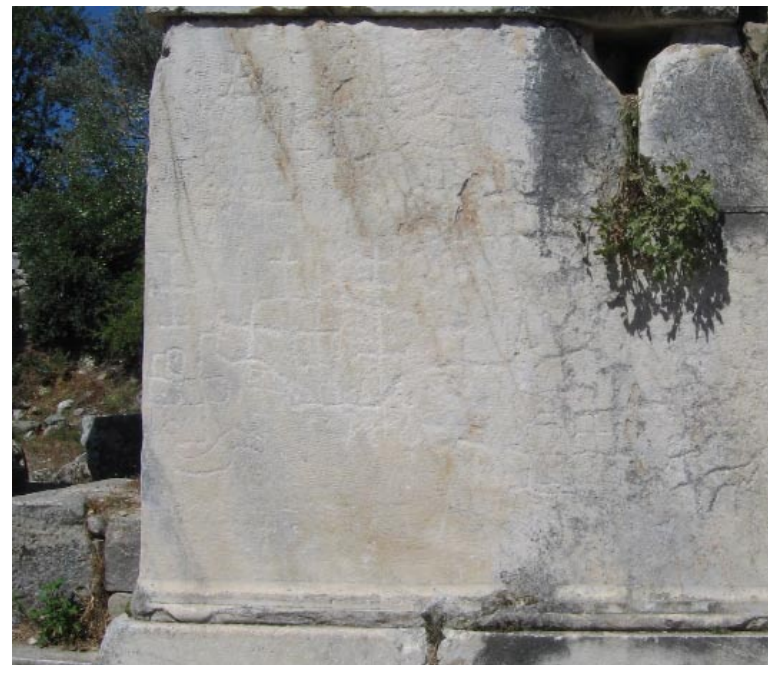

Fig. 9. Crosses on the west pier of the Severan Gate at Stratonikeia (photo author).

Paint or stucco/plaster on walls has only been preserved in a few locations. Moreover, features like this were never systematically recorded, and they may have remained unnoticed in excavations if their state of preservation was poor. ${ }^{72}$ The painted or stucco motif on both the West and the NorthEast Gate of Aphrodisias could only be reconstructed because its field of application in the centre of the tympanon had been carefully prepared.

\section{INSCRIPTIONS ABOVE GATES}

Finally, the addition of an inscription was also unnecessary if the gate was intended to be purely defensive. Nevertheless, in the major cities of the Empire as well as in some small provincial towns, the construction of late antique gates was eternalised in words. ${ }^{73}$ The Golden Gate at Constantinople carried two verses composed of possibly gilded bronze letters, attached to the arch with dowels, testifying to the victory of Theodosius. ${ }^{74}$ Some ten years later, grandiloquent inscriptions were carved above the renovated Portae Tiburtina, Praenestina, and Portuensis at Rome prior to Honorius's triumphal entry in $404 .{ }^{75}$

In other towns, inscriptions above gates were more regular building inscriptions. Late antique epigraphy in Asia Minor is, on the whole, scarce; the only building inscriptions connected to gates with any certainty come from Aphrodisias, which in general possessed the most elaborate late antique epigraphic collection. ${ }^{76}$ That of the West Gate greeted visitors to the city; that on the North-East Gate was directed towards the inside (fig. 6). Paral- 
lel inscriptions are known from other regions but they were apparently not numerous. ${ }^{77}$ Neither the gates of the military settlements on the eastern border nor any of the Christian centres contained epigraphic commemorations.

\section{SPREAD OF REPRESENTATIONAL ELEMENTS}

\section{Gradations between settlements}

From this overview, it is clear that city gates were not purely defensive but had non-functional elements added to them. The degree of elaboration was, however, not the same everywhere. Gates of imperial capitals distinguished themselves by their decoration with freestanding, honorific statuary. In general, these gates and fortifications were also larger. ${ }^{78}$ Finally, eloquent inscriptions extolled the prosperity under imperial rule both to visitors from within and beyond the borders of the Empire.

At first sight, new Christian foci received more elaborate gates than pre-existing cities. However, this contrast is partly the result of a long-lasting disdain for reuse of decorative elements and constructions. The South Gate at Perge and the North Gate at Hierapolis were also fronted with a columnar architecture, whereas the latter, in particular, was provided with extensive relief decoration. Likewise, the North-West Gate of Sagalassos and the Gate of Persecution at Ephesus were further adorned with multiple reliefs. The restored Hellenistic gates of Selge and the Main Gate of Side were no simple constructions. Whether or not these buildings or elements were reused, the fact remains that, in Late Antiquity, they were imposing gate constructions whose form and/or decoration went beyond purely defensive purposes.

The difference between the gates of imperial capitals and new Christian foci, on one hand, and pre-existing settlements, on the other, was more apparent in the fact that the first consciously integrated new (references to) triumphal arches, whereas the other did not. It has already been mentioned that older arches could be incorporated into a city's fortification. It is very likely that this incorporation was a mixture of pragmatic and aesthetic concerns. With a few adjustments, an arch could be reused as a gate. Its structure had to be solid enough to withstand an assault. However, the adjustments required could sometimes take on large proportions, especially if the circuit of the wall needed to be adjusted to allow for its incorporation, as was the case at Kyaneai and Apamea. As a result, one can surmise whether there were other reasons to preserve these monuments in what had become the settlement's principal element of visible infrastructure. The continuous admiration for the arch structures is, however, far less ambiguous in the following examples.

The Golden Gate at Constantinople with its statuary decoration and inscriptions was intended as a triumphal arch for the emperor Theodosius I. Nevertheless, J. Bardill has convincingly shown that it was always meant to be incorporated into a new fortification wall. ${ }^{79}$ Similarly, prior to Honorius's triumphal entry into Rome in AD 404, the Portae Tiburtina, Praenestina, and Portuensis were transformed into triumphal arches with the addition of statues and inscriptions. ${ }^{80}$ The use of this building type - even if only in a simplified form - was continued in the new Christian sanctuaries. The South Gate of the Christian centre at Tebessa with its columnar architecture, arched opening and (reconstructed) high attic storey strongly resembled a traditional arch. The gates of Resafa and the North Gate of Abu Mina comprised three passages - with the central passage larger than those to the side - flanked by pilasters, half-columns or columns. The gate openings at Abu Mina were arched, whilst those at Resafa were covered with a lintel and provided with prominent arcades somewhat higher up the wall.

Finally, the elaboration of the gates at Zenobia was either inexistent or very simple. Nevertheless, the settlement's fortifications were, on the whole, grand and carefully constructed. The size of its gates also greatly outshone that of other cities. ${ }^{81}$ Hence, the lack of further architectural and figurative decoration can be considered a conscious choice.

\section{Decoration according to the degree of visibility}

As suggested earlier, the outer face of the gate possessed the highest degree of visibility, since it was the first edifice with which wayfarers came into contact on entering the city. In addition, as part of the city, the gates were connected and integrated into the total architectonic system. ${ }^{82}$ Especially in cities with a more regular grid plan, the gates were located at the extremities of the main axes - at the end of the major sightlines - so that they were also highly visible from the inside. Consequently, in the Roman period, both faces of a gate would be decorated elaborately. ${ }^{83}$ In contrast, in the Late Roman examples discussed above, additional decorative or representative elements were mostly applied to the exterior face of the gate. ${ }^{84}$ To illustrate this point further, we will discuss in detail some of the more elaborately decorated examples.

To begin with, even the rear side of the Golden 
Gate at Constantinople was constructed from limestone blocks, on which mason's marks were still visible, whereas its front side was finished in marble. There was also a notable difference between the front and rear faces of the integrated door frames, which were not finished - especially at the back and barely fitted the spaces provided. ${ }^{85}$ Finally, on the sides of the towers turned away from the Gate, only the first few Ionic cornice blocks were given dentils, while the others possessed a continuous moulding.

Likewise, throughout the Sanctuary of Tebessa, the gradation in visibility was directly related to the degree of elaboration in the architectural elements. Three levels were incorporated into the design of the gates: 'a triumphal arch' at the highest level, 'gates' on an intermediate level and, finally, no decoration in the least visited and visible area. The South Gate did indeed enjoy the highest level of visibility, as everyone coming to the Sanctuary would have passed through this passage, which was the shortest route in. The exterior face of the North Gate was far less discernible because, in order to reach it, it was necessary to walk around the Sanctuary through the void between the outer and inner fortification. Its southern façade, which was turned towards the interior of the Sanctuary, was again far more visible. Consequently, it was very similar to the interior face of the South Gate in concept and dimensions, as it possessed bases standing on ground level on both sides of the passage. In contrast to the South Gate, the interior façade of the North Gate displayed fewer details: the moulded profiles were only executed to the extent that they could be seen from the avenue, leaving the rear sides blank. ${ }^{86}$ Its northern façade was not decorated at all.

The degree of visibility obviously influenced the decoration on the gates at Resafa as well. On the whole, the decoration on the exterior face of the back wall of the courtyard was far more extensive than that on the inside, where it was limited to a profiled band uniting all passages. Nevertheless, the massive staircases flanking the passages also gave the interior faces of the walls an impressive character. Indeed, the most heavily decorated gate, the North Gate, was constructed from the largest ashlars. ${ }^{87}$ With its columnar architecture, the rear wall that greeted itinerants was the most impressive. The decoration continued on the side walls, but in a flatter version: pilasters with bottom mouldings, pilaster capitals and sham entablature. The supplementary decoration on the side walls resembled that of the rear wall but, in contrast, it was never finished. ${ }^{8}$
There were, however, exceptions to this customary spread of decoration. Firstly, the rear wall of the South Gate at Resafa was adorned with a profiled band along the town side, but remained undecorated on the courtyard side. The passage in the front wall was likewise decorated with a profiled band at the town side, but was left plain on the land side. Could it be that this South Gate was not primarily an entrance to the town, but an exit or end point of the processional route that began at the North Gate? And, analogously, could it also be that the North-East Gate at Aphrodisias, with its inscription turned towards the interior, served primarily as an exit?

It is, in any case, worthy of note that, as a general rule, the interior of gates in Late Antiquity was no longer a major point of attention. Effort was saved for, and concentrated on, the outside. Apparently, representation of the town or settlement to outsiders was regarded as more important then decorating the end points of sight lines within the city itself.

\section{Gradation in importance}

Consequently, we can conjecture whether there was a gradation in importance among the various gates of a town, or whether it possessed one main entrance to be used, for instance, to receive official guests or for secular and religious processions. ${ }^{89}$ In settlements where processions played a vital role - namely Christian sanctuaries - this was apparently the case. In the case of Resafa, it has already been mentioned that the North Gate exhibited the most elaborate decoration, distinguishing it from the other main gates. At Tebessa, the main entrance was through its South Gate. Likewise, at Abu Mina, there was only one richly decorated entrance, which greeted pilgrims after crossing the lake of Mareotis or travelling overland from Alexandria. Similarly, the special meaning of the Golden Gate at Constantinople was connected to the course of a pre-existing triumphal route that began in the suburb of Hebdomon, ca $4 \mathrm{~km}$ outside the land walls. ${ }^{90}$ In other exceptional settlements, such as Split for instance, one major and easily distinguishable entrance existed; in this case, in the north of the enclosure wall. 91

Although the fortifications and circulation patterns of more ordinary towns are less well known, there are strong indications that here certain entrances were favoured above others. In some cities such as Pergamon and Blaundos, only one location existed where wheeled traffic could enter the city. ${ }^{92}$ The position of inscriptions on the exterior face of 
the West Gate and the interior face of the NorthEast Gate of Aphrodisias may indeed be more than coincidental. The North Gate at Hierapolis was decorated more elaborately than its South Gate, even though both were erected astride the city's main colonnaded street. Not only the elaborate decoration of the late antique South Gate but also the preservation of the old Hellenistic Gate as an urban monument and the luxurious decoration of the plaza in-between both constructions implied that the main route into the city centre of Perge was via the south. Likewise, the careful maintenance of monuments situated in the vista of the north-south colonnaded street at Sagalassos, as well as the restorations to the street itself, suggest that the representative entrance to the city was located to the south, even though the course of the fortification wall in this area remains unknown.

\section{REASON FOR APPLICATION}

Why did one go to the trouble of creating decorative façades and integrating figurative reliefs? In the introduction, it was stated that the first contact with a settlement took place at its fortifications and especially its gates. The principal and most general reason for decorating city entrances at that time was undoubtedly representational. The positioning of decoration on gates was highly effective since not only would it be noticed by random travellers but the gate was also the traditional location for official welcomes and processions entering the town. ${ }^{93}$ This custom remained in use until the $13^{\text {th }}$ century: in Konya, ceremonies and official welcomes continued to take place in front of the aforementioned walls, prior to the guests or procession entering the town. Representation of the city was, of course, not limited to the gates but continued along its main streets, its public squares and its communal buildings. In the capital of the Empire, the imperial rulers needed to make themselves manifest not only to their own subjects but also to visitors from abroad. Smaller cities may have been driven by an inter-city rivalry to become the first city of their region. ${ }^{94}$ The importance of Christian sanctuaries was already conveyed to pilgrims when they entered the main gate. In contrast, the imposing but plain architecture of the fortifications and gates of Zenobia can be explained by the fact that the settlement's function was purely defensive. It had no political aspirations and was mainly visited by army units and caravans who were primarily concerned for their safety.

The presence of statues at or near city gates is thus connected to their advantageous location. ${ }^{95}$
We can imagine that for similar reasons of high visibility - but also because they were the weakest points in the defence - gates were the best location to post images intended to scare off potential opponents beforehand or during a siege. ${ }^{96}$ The use of divine images to protect city walls was a more common occurrence in earlier days. For instance, the late $3^{\text {rd }}$ or early $2^{\text {nd }}$ century BC Porta Marzia at Perugia included depictions of Jupiter and the Dioscures, whilst the Arch of Rimini was endowed with imagines clipeatae of protective gods associated with the Roman imperial house such as Apollo and Dea Roma. In the later $3^{\text {rd }}$ century, Cabirius, the tutelary deity of Thessalonica was depicted above an entrance gate on a coin of Gallienus. ${ }^{97}$ These images have been interpreted as providing protection for both the gate itself and for the city on the whole. At Sagalassos, the presence of depictions of Ares and Athena, the warrior gods of the Greek pantheon, on the façade of the North-West Gate fitted aptly with the ancient reputation of the Pisidians as a warlike people. In Late Antiquity, this was still evidenced by the many locally produced figurines of rider saints who replaced the old warrior gods, and by the veneration of St. Michael, the archistrategos of the heavenly army. ${ }^{98} \mathrm{~A}$ similar association with pagan gods can be found at Athens in the same period. In the early $6^{\text {th }}$ century, Zosimus (5.6.) narrated how Alaric abandoned his attack on Athens, having seen Athena and Achilles on the city wall. Thus, in both Sagalassos and Athens, two gods (or one god and a hero), who held a special significance for the city, had been chosen to act as champions in its defence. ${ }^{99}$

Apparently, classical culture was still prominent here in the late $4^{\text {th }}$, early $5^{\text {th }}$ century. ${ }^{100}$ Although the application of reliefs with such explicitly pagan subjects may already have been less than circumspect in this period, it was certainly no longer possible in later centuries. There were, however, more neutral depictions such as lions and snakes, or military reliefs depicting shields, weapons and cuirasses. For them, a Christian association may have been fairly easy to find. As stated previously, they often appeared in combination with crosses - even at a Christian pilgrimage centre such as Resafa - implying that they were not considered offensive. Their integration may have sprung partly from encouragement by the emperors, out of respect for old monuments of artistic and historical value and a willingness to reuse them to embellish the cityscape. However, they must also have been intended to invoke fear and symbolise the strength of the fortifications and the city.

As with figurative reliefs, crosses also con- 
veyed a specific message to visitors and attackers; namely, the inhabitants adhered to the Christian faith and were under the direct protection of the Christian God. At the same time, they may also have called upon His protection. In the $6^{\text {th }}$ century, the need for such spiritual protection would have led to the replacement of pagan gods with the Virgin Mary as guardian of the walls - for example, in Constantinople and in some of the frontier forts. ${ }^{101}$ Finally, the use of crosses may have also served an apotropaic purpose, in seeking to ward off demons from the Christian city. ${ }^{102}$

\section{CONCLUSION}

The virtually ubiquitous presence of fortifications was one of the new elements in the Late Roman city. There can be no doubt that the climate in Late Antiquity was less stable then in prior centuries, making the construction of defensive circuits a sound precaution, if not quite a necessity. Most gates constructed for defensive reasons in the East Mediterranean between the late $4^{\text {th }}$ and the early $7^{\text {th }}$ centuries belonged to the so-called forecourt type of gateway; this usually comprised one passage flanked by two symmetrically positioned and mostly rectangular towers jutting outwards to create a small courtyard in front of the passage. Typically, the aperture itself consisted of just one narrow gate opening, with or without door posts, and a tympanum which combined a lintel and a relieving arch with the intervening field filled in. No further requirements were necessary to keep enemies out.

Nevertheless, this simple pragmatic scheme was, in most instances, supplemented with figurative and/or architectural decoration. The reasons for elaborating late antique gates can be divided into representation - of the importance of the town, its wealth or religious adherence - and psychological defence. The latter in particular required a concentration of elements on the exterior face of the gate. The use of reliefs and crosses on a gate's façade aimed to discourage opponents but it could also make a statement about the beliefs of the town's inhabitants. In contrast, the addition of columnar architecture in front of the gate must have hampered its defence and can be viewed therefore as purely representational. The doubling or tripling of a gate's passageways also weakened defences but ensured the smooth conveyance of traffic in times of peace.

The final appearance of the gates was partially determined by the nature of the settlement. If there was a high degree of inter-urban traffic, as was the case in the capital of the Empire or at international Christian sanctuaries, more than one passage into town was provided. This high visibility ensured a more elaborate decoration, in the form of honorific statuary and inscriptions or lavish architectural adornments often recalling Roman triumphal arches. If the settlement was located in a hostile region, the safest solution was to separate the military function from all others by creating a closed courtyard (cavaedium gate) where the enemy could be stopped at the first entrance, and all other functions could be concentrated at the rear of the courtyard. This occurred at Resafa, and a similar solution was applied at Tebessa. A separation of functions was not deemed necessary in cities such as Perge and Hierapolis, where the main gates were preceded by a columnar architecture. Accordingly, even if such fortifications in Asia Minor were exposed to certain threats and a growing need for security, they apparently had little doubt, in contrast to the settlements on the Persian border, that they would prevail over all difficulties.

\section{NOTES}

* This article is part of my PhD research, carried out as a Research Assistant of the Research Foundation - Flande, under the direction of Prof. M. Waelkens (Katholieke Universiteit Leuven).

1 Von Hesberg 2005, 73. This function is also apparent in the title of a recent colloquium "Stadttor: Bautyp und Kunstform" (Schattner/Fernandez 2006), which dealt with the diverse functions of a city gate from the Hellenistic until the Islamic period, though most examples included in the volume pre-date Late Antiquity. Gates dating to post-Roman periods, in particular, have received a great deal of attention. For example, Gardner 1987, esp. 202-213 discusses medieval gates in Italy; Redford 1993 deals with some Selçuk gates in Turkey; the appearance and meaning of the renaissance gates of Italy have been described and discussed in Schweizer 2002. The importance of city gates found its strongest expression in the work of Père Laugier, Jesuit and later Benedict monk, whose architectural essay of 1753 argued that the beauty of the town depended not only on the street and public buildings but also on its entrances. See Schweizer 2002, 13-14.

2 Towns on the Persian border: Resafa, fortifications erected in the second quarter of the $6^{\text {th }}$ century and Zenobia, early $6^{\text {th }}$ to mid- $6^{\text {th }}$ century; Christian centres: Resafa, Tebessa, constructed at the end of the $4^{\text {th }}$, early $5^{\text {th }}$ century and Abu Mina, in the later $6^{\text {th }}$ century.

3 Adam 1982, 77-104 for an overview of the development of Greek gates.

4 The earliest known example dates back to the $4^{\text {th }}$ century BC, but it was omnipresent during the Hellenistic period. See McNicoll 1997, 7.

5 Winter 1971, 89, fig. 68; 171, fig. 159 for Perge; McNicoll 1997, 129 for weaponry friezes.

6 Gardner 1987, 200; Gros 1996, 35; see von Hesberg 2005, 36, 71-74 for late Republican and Early Imperial Gates 
in Italy; Segal 1997, 86-101 for the Near East.

7 Adam 1994, 48.

8 Axial gateways are less easy to defend but practical for the passage of traffic. See McNicoll 1997, 6; van Tilburg 2008.

9 Gros 1996, 42; Gardner 1987, 199-202; Brilliant 1974, 6365; for some examples, see De Bernardi Ferrero 2002, 111 for Hierapolis; Hakan Mert 2005 for Stratonikeia.

10 Schattner 2006, 13.

11 Brilliant 1974, 65.

12 Schattner 2006, 11-12 with all references; MacDonald 1986, 82

13 Liebeschuetz 1972, 208-209.

14 Elevated sills can be found at the South Gate of Perge, the late $3^{\text {rd }}$ century Gate of Pergamon, the Magnesian Gate at Ephesus, and the North-west Gate of Sagalassos. The first two display traces of wheels.

15 This type occurred in all parts of the Empire: for Spain, where semi-circular towers were popular, see Johnson 1983, 44; Fernández-Ochoa/Morillo 2005, 315. In Gaul, Ushaped as well as round or polygonal towers were used, see Johnson 1983, 46-47. For $6^{\text {th }}$ and $7^{\text {th }}$ century Africa, see Pringle 1981, 160-163. They also were found at the larger castella and towns in Northern Macedonia, see Mikulc ic 2002, 95-96. The only main gate that lacked towers was the one at Pergamon. The gate in the late fortification surrounding the city centre of Ephesus might have been protected by a single tower erected in the north-east corner of the former Tetragonos Agora, see Foss 1979, 112.

16 Meyer-Plath/Schneider 1943, 39-71.

17 For Blaundos, see Giese 2006b; Hierapolis, D'Andria 2003, 112-114, 203; Aphrodisias, Smith/Ratté 2000, 238 240; Sagalassos, Loots/Waelkens/Depuydt 2000, 614, 619-625.

18 For Resafa, Karnapp 1976, 6-29; Zenobia, Lauffray 1983, 128-132; Ephesus, Thiel 2005, 115.

19 These are clearly recognisable in the so-called first secondary gate at Constantinople, the North Gate at Blaundos, Hierapolis, Aphrodisias (with reused arches), the North-west Gate at Sagalassos, the South Gate at Perge, the restored gates at Selge, the gates at Zenobia and Resafa, and the passages in the Inner Fortifications at Side.

20 Meyer-Plath/Schneider 1943, 39, fig. 7.

21 Examples include the first secondary gate at Constantinople and the Gate of Persecution at Ephesus.

22 McNicoll 1997, 7, 100 for Ephesus.

23 See, for instance, MacDonald 1986, figs. 75-83.

24 Bührig 2006, 133. MacDonald 1986, 84 considered freestanding arches as reproductions of the original city gate but without the structural and functional context.

25 There are only a few examples of other monuments transformed into city gates, presumably because their shape was not suited for this purpose. The only exception was the propylon of the Library of Hadrian at Athens - which was in fact similar in shape and even function to an arch - that was incorporated as a gate into the post-Herulian wall. See Fowden 1997, 553-556.

26 A sequence of representational Imperial gates and defensive late antique gates can, for example, be witnessed at Gadara in present-day Jordan: the first gate of the town, the West Gate, was still intended to be defensive; in AD 70, a representational arch, the Tiberias Gate, was erected in front of the defences; at the beginning of the $3^{\text {rd }}$ century, a new decorative arch/gate with three passages was constructed rather more to the west however, when the need for defence was again felt 80 years later, a fourth gate with a completely different appearance, following the basic scheme described above, was erected as part of the new fortifications. See Bührig 2006, 143-151.

27 At other sites, the narrowing of the original passage was achieved by extending the existing wall sections as, for instance, took place at the East Gate of Side or the South Gate of Perge. The double-portaled gates of the Aurelianic wall at Rome were reduced to single entrances by the insertion of stones gate-houses, see Todd 1983, 61 .

28 Hansen 1996, 30.

29 For the Near East, see, for example, Mazor / Bar-Nathan 1998, 27, 29 (North-east Gate and West Gate of Scythopolis); Segal 1997, 86-87 (Tiberias); Arnould 1997, 196211 (Damascus Gate at Jerusalem); for North Africa, see Goodchild / Ward-Perkins 1953, 49-51; Bardill 1999, 691692 (Leptis Magna); Pringle 1981, 158 (Thubursicu Bure); Christern 1976, 20-23 (Tebessa/Theueste).

30 Van Tilburg 2008.

31 Bardill 1999.

32 Grossmann 1991, 465-467.

33 Giese 2006a, 72

34 Mansel 1968, 242-243.

35 Karnapp 1976, 29-46. They belonged to the more complicated scheme known as the cavaedium gate. The towers of these gates were connected by two parallel walls, leading to the creation of a rectangular courtyard encircled by high walls. In periods of war, this functioned as a defensive sluice, as an extra barrier and open trap for assailants who had breached the front wall. In times of peace, it formed a majestic vestibule between the countryside and the town. For a full description of the type, see Gros 1996, 37-42; Brilliant 1974, 63-64. Although such gates were mainly popular in Italy and southern Gaul in the late years of the Republic and in the first decennia of the Imperial Age, examples also occurred in North Macedonia, where many cities were again fortified in the $4^{\text {th }}$ century AD. See Mikulčić 2002, 95-96. 36 Bardill 1999, 682. These sparsely decorated gates strongly contrast with the intricate patterns found at the Palace of Diocletian in Split, built a century earlier. See McNally 1996, 24-26.

37 Lauffray 1983, 129, 132

38 Lauffray 1983, 131 for a detailed description.

39 A full description of the gates can be found in Karnapp 1976, 37-46 (North Gate), 29-32 (East Gate), 32-34 (South Gate) and 35-37 (West Gate).

40 Christern 1976, 36-43. It is worthy of note that the Gate strongly resembled the Arch (tetrapylon) of Caracalla situated in the city centre, at the crossing of the cardo and the decumanus: not only did it have two sets of two columns to mark the passage, but its dimensions were nearly the same. It is thus highly likely that it was inspired by this tetrapylon.

41 Grossmann 1991, 467.

42 The wall section comprising the passage is thought to have pre-dated the reconstruction of the fortification wall.

43 See ala2004, 139 for the South-east Gate, ala2004, 22 and 42 for the North-east Gate.

44 Giese 2006b, 81.

45 For Perge, see note 5; for Patara, Işık 2000, 82.

46 The date of this late fortification is still uncertain. Recent publications prefer a date in the early $7^{\text {th }}$ century. See Scherrer 2001, 80

47 For instance, on the walls of Nicopolis, all vital points were executed in stone.

48 For example, the gateways at Fano (Iulia Fanestris) and 
at Rimini possessed an arch-like passage with statues at the top, see Richmond 1933, 156-158 (Fano), 160-161 (Rimini).

49 Lauter 1972 for the original Hellenistic Gate at Perge Boatwright 1993 for changes in the Roman period; Mansel 1963, 36-7 for Side.

50 Bassett 2004, 95-96 for a discussion and further bibliography. In addition, flying eagles were carved on the corners of the tower cornices.

51 The statues of the Golden Gate were most likely a mixture of new works, such as the statue of Theodosius or the Tyche, and reused statues taken from elsewhere, such as the bronze elephants. See also MacDonald 1986, 94 for the presence of statuary and elephant spans above arches.

52 CIL 6, 1188-1190; also Richmond 1930, 31-34, 'simulacra constituit'; Gardner 1987, 201.

53 McNally 1996, 25 provides an overview of all provisions.

54 In addition to the fragments belonging to two lions, there was also a head of a lioness and a torso of a sphinx. Other remains included a $1.03 \mathrm{~m}$ high relief depicting a shield decorated with a helmet. This and the fragments of another weaponry relief probably belonged to the original gate but were apparently reused in all later phases.

55 Van Zanten/Thomas/Hanfmann 1975, 45-47.

56 Reliefs of circular shields were a common motif in Pamphylia, Pisidia and Lycia in the Hellenistic period, see McNicoll 1997, 129. In contrast, in other provinces of the Roman Empire, the use of reliefs stressing military characteristics was rare; see von Hesberg 2005, 74

57 Mansel 1968, 243-244. Since the reliefs were mainly found in the eastern part of the terrace and face upwards, this indicated that they were definitely intended to be viewed from the outside.

58 Machatschek/Schwartz 1981, 36-46. Reliefs were present at the small gate in wall stretch M6; the larger gates near M23; at M30-31; four gates in the wall stretches M4041; the representational gates at M44-45 and M70. The most extended display of weaponry friezes was located above gate M70: the two pilasters of the gate were decorated with reliefs on three sides, the first depicting armour on the front, a naked boy on the right-hand side and a head in the upper section on the left-hand side; the second also with armour on the front, a torch in a wreath and a column on the left-hand side. The curtain wall displayed a horizontal frieze, with shields above the passage and armour on the adjoining wall sections. The shield relief visible above one of the gates in wall section M40-41 was clearly incorporated at a later period, as it was positioned in-between a mixture of ashlars of different sizes, supplemented by rubble. Moreover, its off-centre position would have been unusual for the Hellenistic (or Roman) period.

59 Weaponry reliefs were also found at the so-called South Gate, located over the town's main colonnaded street, but recent excavations were unable to ascertain whether or not this structure functioned as a fortified entrance to the town centre.

60 D'Andria 2003, 112-114.

61 Karnapp 1976, 43, fig. 211.

62 Simple elements such as wreaths also appeared on other gates and could be executed in other materials. For instance, both the West and the North-East Gate at Aphrodisias had a painted or stucco motif (possibly a wreath) in a carefully prepared circular surface in the centre of the tympanum.

63 At Ephesus, an acanthus frieze adorns the gateway and a sarcophagus relief with grape-gathering cupids is arranged above it. Originally, there were others inserted in the wall, representing Odysseus's discovery of Achilles among the daughters of king Lykomedes on the island of Skyros. On one of these, Achilles and Hector were depicted (now in the Woburn Abbey Gallery in England). See Miltner 1958, 125-126. The incorporation of reliefs at Ankara included some statues laid on their sides and some blocks that once belonged to a balustrade. See Foss / Winfield 1986, 135

64 Redford 1993, 153-156.

65 Crow 2001, 95-96. At Thessalonica, the brick band inbetween the two rows of double arches was underneath each arch interrupted by the insertion of a brick cross. There was considerable variation: smaller crosses that were surrounded by a green rubble section in order to distinguish them from the brick background, and larger crosses that were clearly visible by themselves and did not need further emphasis. Similar crosses also appeared in the eastern wall section. At Nicopolis, the locations where two construction teams met were occasionally marked by brick crosses. It is unlikely that these served a decorative function.

66 ala2004, 22 and 42.

67 At Stratonikeia, both the gate and the area around it were completely covered in crosses and similar emblems. For Aphrodisias, see ala2004, 139. Invocations were arranged around the cross; the contents of these inscriptions would suggest the $5^{\text {th }}$ or $6^{\text {th }}$ century.

68 Foss 1996, 14.

69 Van Zanten/Thomas/Hanfmann 1975, 45-47.

70 Mansel 1968, 243-244.

71 Karnapp 1976, 35-37.

72 For instance, fragmentary remains of stucco and plaster imitating pseudo-isodomic masonry have been encountered on only a few wall sections at Sardis and Caesarea. See Van Zanten/Thomas/Hanfmann 1975, 39-40 for Sardis; Lehmann 1994, 127 for Caesarea.

73 An earlier example, among others, can be found at the West Gate of Antioch in Pisidia, see Mitchell/Waelkens 1998, 96-99.

74 HAEC LOCA THEVDOSIUS DECORAT POST FATA TYRANNI on the eastern, inside face and AVREA SAECLA GERIT QVI PORTAM CONSTRVIT AVRO on the western outside face.

75 See note 54; Todd 1983, 61

76 Respectively ala2004, 19 and ala2004, 22, 42. Also, in the Inner Fortifications at Side, a late antique building inscription has been retrieved, but this was probably in a secondary position. See Foss 1977.

77 For instance, on inscriptions commemorating the erection of the post-Herulian wall at Athens, see IG II/III2, nos 5199 and 5200; Sironen 1994, 21-22; the Greek Anthology 9.688 mentions the erection of a Gate at Argos and the man who built it; Pringle 1981, appendix CB cites building inscriptions of $6^{\text {th }}$ and $7^{\text {th }}$ century gates of North Africa.

78 The middle passage of the Golden Gate was $15.50 \mathrm{~m}$ high and the side passages $10.88 \mathrm{~m}$. The height of the passage in the North Gate at Blaundos was estimated at ca $2.8 \mathrm{~m}$, and the passage in the South Gate of Zenobia at $4.60 \mathrm{~m}$. The towers of the Golden Gate measured $18.32 \times 16.87 \mathrm{~m}$, those of Blaundos $7.63 \times 7.08$ and $7 \times 7.88 \mathrm{~m}$ (field side); those of the South Gate of Zenobia $18.20 \times 9.75$ and $17.85 \times 9.20 \mathrm{~m}$.

79 Bardill 1999, 690-696.

80 See note 54 .

81 See note 81 . 
82 Gros 1996, 42; Schattner 2006, 9.

83 For instance, at Selge, the original functional gate near wall sections M44-45 was rebuilt as a representational arch in the $2^{\text {nd }}$ century AD, see Machatschek/Schwartz 1981, 40 .

84 The only possible exceptions seemingly occurred at Selge, where some of the gates had more decoration on the interior than on the exterior. For instance, between M13 and M14, a postern gate leading to the southern valley exhibited a simple lintel on the exterior, but an arch with a moulded archivolt resting on top of finely carved impost blocks on the inside.

85 Bardill 1999, 682.

86 Also, mouldings were not continuous on the southern façade of the South Gate but stopped behind the most easterly passage. This would have remained largely invisible since visitors approached the arch from a sharp corner to the west.

87 While those used in the other wall sections and gates had a height of $0.60-0.80 \mathrm{~m}$, those on the North Gate were 1.06 $\mathrm{m}$ high, while the longest stone measured $1.70 \mathrm{~m}$.

88 The decoration on the top band of the eastern wall only continued for the first $0.60 \mathrm{~m}$, after which it adopted a simpler profile. On the western side, the decorated band continued until the second pilaster.

89 Such processions started in front of the gates and moved over the major thoroughfares of the settlement. For processions in general see Halfmann 1986; Bauer 1996, 389394; for processions at Constantinople, Bauer 2001.

90 Bardill 1999, 693, fig. 17.

91 McNally 1996, 25.

92 For the connection between wheeled transport and interurban traffic, see van Tilburg 2008.

93 Liebeschuetz 1972, 208-209.

94 Lavan 2008, 208.

95 Richmond 1933 and Gardner 1987, 202.

96 von Hesberg 2005, 71, cf. infra.

97 Gros 1996, 35 for Perugia; Schattner 2006, 12 for Ariminium; Touratsoglou 1988, pl. 45, R16 for Thessalonica; Maier 1961 gives examples of the Greek world, together with a discussion on the functions of these depictions. Examples of the Roman period can be found in Seston 1966

98 Mitchell 1995, 26-28. Until the second half of the $3^{\text {rd }}$ century, Sagalassos was involved in the military campaigns against the Parthians and the Sassanians (Talloen 2003, 90$100,119)$. In the $5^{\text {th }}$ century, there was still an elaborate production of figurines depicting Christian priests or saints and warrior figures on horseback, the latter also appearing on the locally produced decorated pottery. They can be seen as the descendants of the indigenous warrior deities on horseback (Talloen 2003, 185-6, 195). For the cult of St. Michael in Sagalassus, see Talloen 2003, 192.

99 Fowden 1997, 556-558. Apparently, classical culture was still prominent in the late $4^{\text {th }}$, early $5^{\text {th }}$ century at both Sagalassos and Athens.

100 See Uytterhoeven in press for similar 'survivals' in the better known domestic contexts.

101 Gardner 1987, 202

102 Crow 2001, 98; Gardner 1987, 202. For this reason, crosses were carved on all entrances.

\section{BIBLIOGRAPHY}

ala2004: C. Roueché, Aphrodisias in Late Antiquity: The Late Roman and Byzantine Inscriptions, revised second edition., <http: / / insaph.kcl.ac.uk/ala2004>
Adam, J.-P. 1982, L'Architecture militaire grecque, Paris.

Adam, J.-P. 1994, Roman Building. Materials and Techniques, London/New York.

Arnould, C. 1997, Les Arcs romains de Jérusalem (Novum Testamentum et Orbis Antiquus 35), Freiburg.

Bardill, J. 1999, The Golden Gate in Constantinople: a triumphal Arch of Theodosius I, AJA 103, 671-696.

Bassett, S. 2004, The Urban Image of Late Antique Constantinople, Cambridge.

Bauer, F.A. 1996, Stadt, Platz und Denkmal in der Spätantike. Untersuchungen zur Ausstattung des öffentlichen Raums in den spätantiken Städten Rom, Konstantinopel und Ephesos, Mainz.

Bauer, F.A. 2001, Urban Space and Ritual: Constantinople in Late Antiquity, $A A A H$ 15, 27-61.

Boatwright, M. 1993, The city gate of Plancia Magna in Perge, in E. D'Ambra (ed.), Roman Art in Context: an Anthology, s.l., 189-207.

Brilliant, R. 1974, Roman Art from the Republic to Constantine, London.

Bührig, C. 2006, Die Architektur des Stadteingangs in den östlichen Provinzen des Römischen Reiches. Stadttor und Bogenmonument, in T.G. Schattner/F.V. Fernandez (eds.), Stadttore. Bautyp und Kunstform. Akten der Tagung in Toledo 2003, Mainz, 131-152.

Christern, J. 1976, Das frühchristliche Pilgerheiligtum von Tebessa. Architektur und Ornamentik einer spätantiken Bauhütte in Nordafrika, Wiesbaden.

Crow, J. 2001, Fortifications and urbanism in late antiquity: Thessalonica and other eastern cities, in L. Lavan (ed.), Recent Research in Late-Antique Urbanism (JRA Suppl. 42), Portsmouth, 89-105.

D'Andria F. 2003, Hierapolis di Frigia (Pamukkale). Guida Archeologica (Città antiche dell' Anatolia 5), Istanbul.

De Bernardi Ferrero, D. 2002, Architettura e decorazione di età flavia a Hierapolis di Frigia, in D. De Bernardi Ferrero (ed.), Saggi in Onore di Paolo Verzone (Hierapolis Scavi e Ricerche 4), Rome, 1-44.

Fernández-Ochoa C./A. Morillo 2005, Walls in the urban landscape of Late Roman Spain: defense and imperial strategy, in K. Bowes/M. Kulikowski (eds.), Hispania in Late Antiquity (The Medieval World and Early Modern Iberian World 24), Leiden/Boston, 299-340.

Foss, C. 1977, Attius Philippus and the walls of Side, ZPE 26, 172-180.

Foss, C. 1979, Ephesus after Antiquity. A Late Antique, Byzantine and Turkish City, Cambridge.

Foss, C. 1996, The cities of Pamphylia in the Byzantine age, in Cities, Fortresses and Villages of Byzantine Asia Minor, Aldershot, IV, 1-62.

Foss, C./D.Winfield 1986, Byzantine Fortifications. An Introduction, Pretoria.

Fowden, G. 1997, Late Roman Achaea: identity and defence, JRA 8, 549-67

Gardner, J. 1987, An Introduction to the Iconography of the Medieval Italian City Gate, DOP 41, 199-213.

Giese, J. 2006a, Die Stadtbefestigung. Die Stadtmauer: Mauerring und Türme, in A. Filges (ed.), Blaundos. Berichte zur Erforschung einer Kleinstadt im lydisch-phrygischen Grenzgebiet, Tübingen, 67-78.

Giese, J. 2006b, Die Stadtbefestigung. Das Nordtor, in A. Filges (ed.), Blaundos. Berichte zur Erforschung einer Kleinstadt im lydisch-phrygischen Grenzgebiet, Tübingen, 79-114. Goodchild, R.G./J.-B. Ward-Perkins 1953, The Roman and Byzantine defences of Lepcis Magna, BSR 21, 42-73. Gros, P. 1996, L'architecture romaine: de début de IIIe siècle av. J.-C. à la fin du Haut-Empire 1. Les monuments publics, Paris. 
Grossmann, P. 1991, Abu Mina. 12. Vorläufiger Bericht. Kampagne 1984-1986, AA 1991, 457-486.

Halfmann, H. 1986, Itinera Principum: Geschichte und Typologie der Kaiserreisen im römischen Reich, Wiesbaden.

Hakan Mert, I. 2005, Die Tor- und Nymphaeumanlage von Stratonikeia, in D. Kreikenbom/K.-U. Mahler/T.M. Weber (eds.), Urbanistik und städtische Kultur in Westasien und Nordafrika unter den Severern. Beiträge zur Table Ronde in Mainz am 3. und 4. Dezember 2004, Worms, 241-251.

Hansen, C.G. 1996, Ein dreitoriger Ehrenbogen in Kyaneai, in F. Kolb (ed.), Lykische Studien 3. Die Siedlungskammer von Kyaneai in Lykien. Bericht über Feldforschungen im Yavu-Bergland im Sommer 1992, Bonn, 21-30.

Işık, F. 2000, Patara. The History and Ruins of the Capital City of Lycian League, Antalya.

Johnson, S. 1983, Late Roman Fortifications, London.

Karnapp, W. 1976, Die Stadtmauer von Resafa in Syrien (Denkmäler Antiker Architektur 11), Berlin.

Lauffray, J. 1983, Halabiyya-Zenobia. Place Forte du Limes Oriental et la Haute-Mésopotamie au VIe Siècle, 1. Les Duchés frontaliers de Mésopotamie et les fortifications de Zenobia, Paris.

Lauter, H. 1972, Das hellenistische Südtor von Perge, BJb $172,1-11$.

Lavan, L. 2008, The monumental streets of Sagalassos in late antiquity: an interpretative study, in P. Ballet/N. Dieudonné-Glad/C. Saliou (eds.), La rue dans l'Antiquité. Définition, aménagement et devenir (Poitiers, 7-9 Septembre 2006), 201-214.

Lehmann, C.M. 1994, The combined Caesarea expeditions: the excavation of Caesarea's Byzantine City Wall, 1989, AASOR 52, 121-131.

Liebeschuetz, J.H.W.G. 1972, Antioch. City and Imperial Administration in the Later Roman Empire, Oxford.

Loots, L. / M. Waelkens/F. Depuydt 2000, The city fortifications of Sagalassos from the Hellenistic to the late Roman period, in M. Waelkens/L. Loots (eds.), Sagalassos V. Report on the Survey and Excavation Campaigns of 1996 and 1997, Leuven, 595-634.

Macdonald, W.L. 1986, The Architecture of the Roman Empire II. An Urban Appraisal, New Haven.

Machatschek, A./ M. Schwarz 1981, Bauforschungen in Selge, Vienna.

Maier, F.G. 1961, Torgötter, in Eranion. Festschrift für Hildebrecht Hommel, Tübingen, 93-104.

Mansel, A.M. 1963, Die Ruinen von Side, Berlin.

Mansel, A.M. 1968, Osttor und Waffenreliefs von Side (Pamphylien), AA 1968, 239-279.

Mazor, G./R. Bar-Nathan 1998, The Bet She'an Excavation Project 1992-1994. Antiquities Authority Expedition, ESI 17, 2-36.

McNally, S. 1996, The Architectural Ornament of Diocletian's Palace at Split (BAR Int. Ser. 639), Oxford.

McNicoll, A.W. 1997, Hellenistic Fortifications from the Aegean to the Euphrates, Oxford.

Meyer-Plath, B./A.M. Schneider 1943, Die Landmauer von Konstantinopel 2: Aufnahme, Beschreibung und Geschichte (Denkmäler antiker Architektur 8), Berlin, 39-71.

Mikulčić, I. 2002, Spätantike und frühbyzantinische Befestioungen in Nordmakedonien. Städte, Vici, Refugien, Kastelle (Müncher Beiträge zur Vor- und Frühgeschichte 54), Munich.

Miltner, F. 1958, Ephesos. Stadt der Artemis und des Johannes, Vienna.

Mitchell S. 1995b, Anatolia. Land, Men and Gods in Asia Minor 2. The Rise of the Church. Oxford.

Mitchell, S. / M. Waelkens 1998, Pisidian Antioch. The Site and its Monuments, London.
Pringle, D. 1981, The Defence of Byzantine Africa from Justinian to the Arab Conquest. An Account of the Military History and Archaeology of the African Provinces in the Sixth and Seventh Centuries (BAR Int. Ser. 99), Oxford.

Redford, S. 1993, The Seljuqs of Rum and the Antique, in Muqarnas 10. Essays in Honor of Oleg Grabar, Leiden, 148-156.

Richmond, I.A. 1930, The City Wall of Imperial Rome. An Account of its Architectural Development from Aurelian to Narses, Oxford.

Richmond, I.A. 1933, Commemorative arches and city gates in the Augustan age, JRS 23, 149-174.

Schattner, T.G. 2006, Einführung, in Schattner/Fernandez, 9-14.

Schattner, T.G./F.V. Fernandez (eds.), Stadttore. Bautyp und Kunstform. Akten der Tagung in Toledo 2003, Mainz.

Scherrer, P. 2001, The historical topography of Ephesos, in D. Parrish (ed.), Urbanism in Western Asia Minor. New Studies on Aphrodisias, Ephesos, Hierapolis, Pergamon, Perge and Xanthos (JRA Suppl. 45), Portsmouth, 57-93.

Schweizer, S. 2002, Zwischen Repräsentation und Funktion. Die Stadttore der Renaissance in Italien (Veröffentlichungen des Max-Planck-Instituts für Geschichte 184), Göttingen.

Segal, A. 1997, From Function to Monument. Urban Landscapes of Roman Palestine, Syria and Provincia Arabia, Oxford.

Seston, W. 1966, Les murs, les portes et les tours des enceintes urbaines et le problème des res sanctae en droit romain, in R. Chevallier (ed.), Mélanges d'Archéologie et d'Histoire Offerts à André Piganiol 3, Paris, 1489-1498.

Sironen, E. 1994, Life and Administration of Late Roman Attica in the Light of Public Inscriptions, in P. Castrén (ed.), Post-Herulian Athens. Aspects of Life and Culture in Athens AD 267-529, Helsinki, 15-62.

Smith, R.R.R./C. Ratté 2000, Archaeological Research at Aphrodisias in Caria, 1997 and 1998, AJA 104, 221-253.

Talloen, P. 2003 Cult in Pisidia. Religious Practice in Southwestern Asia Minor from the Hellenistic to the Early Byzantine Period, unpublished PhD dissertation, KULeuven.

Thiel, A. 2005, Die Johanneskirche in Ephesos, Wiesbaden.

Todd, M. 1983, The Aurelianic wall of Rome and its analogues, in J. Maloney/B. Hobley (eds.), Roman Urban Defences in the West (CBA Research Report 51), London, 58-67.

Touratsoglou, I. 1988, Die Münzstätte von Thessaloniki in der römischen Kaiserzeit (32/31 v.Chr. bis 268 n.Chr.), Berlin.

Uytterhoeven, I. in press, Know your classics. Classical tradition in late antique domestic contexts, in P. Van Nuffelen (ed.), Faces of Hellenism, Leuven.

Van Tilburg, C. 2008, Gates, suburbs and traffic in the Roman Empire, BABESCH 83, 133-147.

Van Zanten, D./R.S. Thomas / G.M.A. Hanfmann 1975, The city walls, in G.M.A. Hanfmann/J.C. Waldbaum (eds.) A Survey of Sardis and the Major Monuments outside the City Wall (Archaeological Exploration of Sardis. Report 1), Harvard, 35-53.

Von Hesberg, H. 2005, Römische Baukunst, Munich.

Winter, F.E. 1971, Greek Fortifications, Toronto.

\section{BLIJDE INKOMSTSTRAAT 21}

B-3000 LEUVEN

ine.jacobs@arts.kuleuven.be 
|1980-09_Babesch_14_Jacobs 10-02-2009 13:17 Page 214 